PREPARED IN COOPERATION WITH THE

STATE OF CONNECTICUT

GEOLOGICAL AND NATURAL HISTORY SURVEY

\title{
AEROMAGNETIC MAP OF PARTS OF THE WHITE PLAINS AND GLENVILLE QUADRANGLES, WESTCHESTER COUNTY, NEW YORK AND FAIRFIELD COUNTY, CONNECTICUT,
}

GEOPHYSICAL INVESTIGATIONS

MAP GP-825

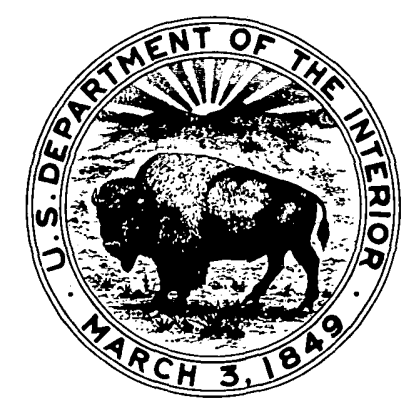

